\title{
ARTHRITIS IN RATS PRODUCED BY PLEURO-PNEUMONIA-LIKE ORGANISMS
}

\author{
BY \\ M. W. PARKES and FRED WRIGLEY* \\ WITH THE TECHNICAL ASSISTANCE OF MISS B. O'BRIEN
}

Attempts to produce in animals conditions resembling various rheumatic diseases have been numerous and have employed a wide variety of agents. Such work has usually had as its object the investigation of the part played by a certain factor in the causation of rheumatic conditions or the provision of animal subjects to test the efficacy of therapeutic agents. The work reported here was undertaken with the latter object in view.

The agent selected was a strain of pleuro-pneumonia-like organism (PPLO). This group has been surveyed by Sabin (1941) and Dienes (1945) who deal particularly with their morphology and characterization. There seems to be no evidence for associating rheumatoid arthritis with PPLO infection; attempts to isolate the organism from cases of rheumatoid arthritis have been unsuccessful (Preston, 1942). However, PPLO has been isolated from spontaneously occurring polyarthritis in rats; injection of this material into rats has been said to produce progressive changes of an arthritic nature in the joints. (Cf. also Collier and Staverman, 1940.)

Work with this organism, in rats and mice, has been reviewed by Findlay (1946). Detailed comparisons of a number of strains of PPLO isolated from animals have been made by Klieneberger $(1938,1940)$. One such strain, designated " $\mathrm{L}_{\mathbf{4}}$ ", is characterized by the production of abscesses, adenitis, and arthritis; this strain has been serologically identified with those employed by earlier workers on experimental arthritis in rats using PPLO. Tripi and Kuzell (1947, 1949) used a known $\mathrm{L}_{4}$ strain of PPLO to produce experimental arthritis in rats.

Sabin (1939, 1940) and Preston (1942) describe pathological changes occurring in the joints of experimental animals injected with cultures of PPLO. Sabin regards the condition produced in mice as resembling human rheumatoid arthritis in its clinical course and pathology, but Preston (1942) finds that the changes occurring in rats more closely resemble pyogenic joint infections in man.

\section{Experimental Procedure}

A strain of PPLO $\left(\mathrm{L}_{4}\right)$ was used which was said to be capable of producing arthritis in rats. The organisms were cultured in the medium described by Edward (1947) and subcultures were made at intervals of 7 or 14 days. Thallium acetate was included as a

* Research Department, Roche Products Ltd., Welwyn, Herts. 
bacteriostatic in cultures of isolated material, but in material for injection it was omitted. Cultural details of this organism are described by Edward (1950).

For the purposes of this work it was decided to inject, directly into the blood stream, $0.5 \mathrm{ml}$. of a subculture, in semi-solid medium, of 48-hours' incubation. The route most frequently used was intravenous, although the intracardial route was occasionally employed. The animals used throughout were male Wistar rats of about $150 \mathrm{~g}$. weight.

\section{Results}

The most common sequel to injection by either route was swelling of the hind feet, usually of the plantar surface, occasionally accompanied by redness and tenderness. The swelling was often transitory and showed a tendency to subside and reappear at intervals. Less commonly the swelling involved the region of the ankle joints. The forepaws were very rarely affected. In many cases swellings were first observed 3 to 5 days after injection, which agrees with the period reported by Preston (1942), although the first appearance was often delayed beyond this.

Injected animals frequently showed subsequent loss of weight and in some cases a lowered body temperature and general depression, usually followed by death. Other symptoms, observed more rarely, included swollen testes, and conjunctivitis, both of which have been described by Tripi and Kuzell (1947) as resulting from injection of rats with PPLO. The only abnormalities of any significance observed on post-mortem examination were abscesses. These developed in a number of animals, most frequently in the lungs, which were often extensively involved even in animals appearing quite healthy until they were killed. Abscesses were found more often after intracardial injection than after intravenous injection. From all these abscesses PPLO could be isolated, usually in pure culture. Frequently, necrotic areas developed on the tail at or near the site of injection. An abscess was occasionally found in association with such a necrotic area, and, from such abscesses also, PPLO could be isolated. It was not found possible to isolate PPLO from any other site in infected rats, even from hearts which showed histological changes (vide infra). Culture of swollen joints has not resulted in recognizable colonies of PPLO. However, the tarsal and metatarsal regions of the limbs of two rats showing swellings of the plantar surface were skinned and ground in saline and the filtrate injected into the plantar region of the right foot in six rats. All developed swellings in both feet and showed pathological changes of the joints and slight changes in the heart muscle, similar to those following injection of PPLO culture.

A study of the data collected shows that several tendencies appear to characterize the behaviour of cultures of PPLO in their pathogenicity towards the rat. Progressive subculturing in vitro tends to reduce pathogenicity; abscesses were not produced after injection of material subcultured more than eighteen times, and the power of producing limb swellings and histological changes was also reduced after more than 33 subcultures. Tripi and Kuzell (1947) describe changes in pathogenicity with repeated subculture, which they term "passage", stating that 28 stages were necessary to produce joint swellings without peritonitis, following intraperitoneal injection. We found that animal passage increased the pathogenicity thus allowing maintenance of active cultures of the strain. The severity of the histological changes increased with repeated passage, an effect which, however, disappears with further subculture in vitro. Such an effect has been described by Preston (1942).

We attempted to preserve material with a known degree of pathogenicity by 
freeze-drying. However, there is a tendency for such freeze-dried material gradually to lose the power of producing cultures capable of causing limb swellings.

\section{Histological Changes}

The joints and hearts of rats killed 14 to 21 days after injection were examined.

Joints.-In 64 out of 96 animals, inflammatory changes, mostly of a purulent nature, were found in the peri-articular structures. Changes of the joint surfaces, the synovial membrane, and the synovial fluid were also observed in some cases. Other changes included haemorrhage into the marrow and, in severe cases, dissolution of the articular cartilage. The infiltrating cells included large numbers of histiocytes (macrophages) and neutrophils; some lymphocytes and plasma cells were also seen. In addition multinuclear giant cells were seen in one case near necrosing bone and cartilage. Examination of two severely affected joints suggested that a mass of exudate had lodged between the articular surfaces and had become heavily infiltrated with round cells and neutrophils. This was accompanied by extensive fibrosis which had united the infiltrated mass with the surrounding tissues. There was breakdown of the cartilage matrix on one of the joint surfaces and this had permitted masses of infiltrating cells to penetrate through the head of the bone into the marrow (Figure).

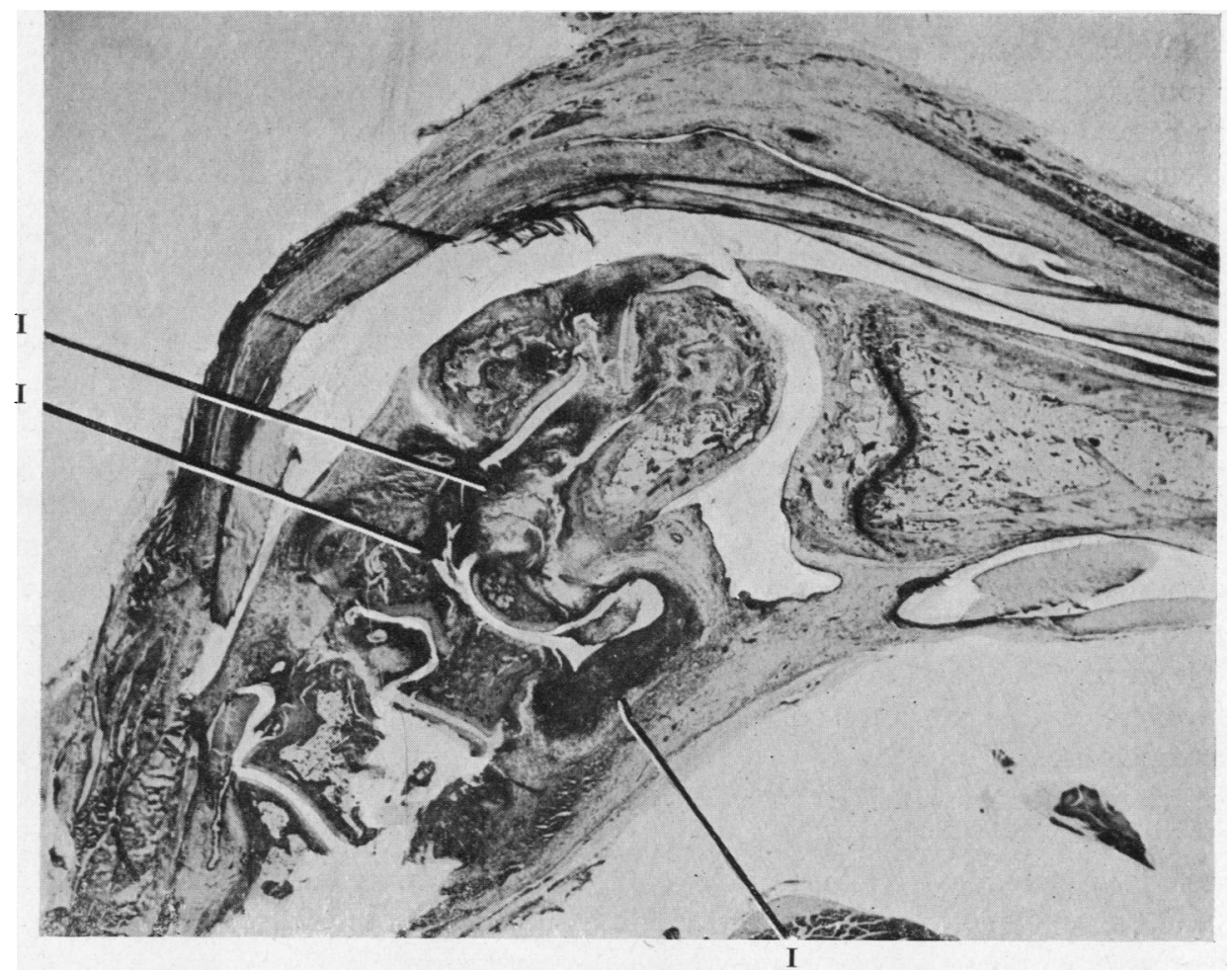

FIGURE.-Section of ankle joint of rat showing areas of inflammation.

I. Regions showing marked inflammatory action.

Hearts. - The PPLO strain used in this work appeared not only to have a predilection for joints but also caused histological changes in the hearts in more than two-thirds of the animals used. 
Out of 96 animals, 58 showed some degrees of change in the myocardium, mostly of an inflammatory nature, and characterized by the presence of cells of the types described as associated with the joint lesions.

\section{Discussion}

These studies were undertaken to produce a method for screening substances for use in the treatment of the rheumatic diseases. Kuzell and others (1949) claimed to have screened a number of substances by inducing arthritis with an $\mathrm{L}_{4}$ strain of PPLO. The course of the disease is favourably altered by gold salts and aureomycin compares well with these substances when given in the food or parenterally; salazopyrin and cupralene exerted some beneficial effect. Sodium gentisate and cinchophen were ineffective. Kuzell and Mankle (1950) reported that terramycin had a favourable effect on the course of the disease, but that cortisone had none.

We felt that a combination of clinical and histological evaluation might enable us to draw conclusions as to which of the many manifestations of rheumatic disease our condition resembled and also to be more certain of the results of our injections.

When abscesses appeared, we decided that further passage and subculture should be undertaken in the hope that, when the more obvious infective element had been eliminated, we should be able to produce at will joint swellings of a rheumatoid type with some of the histological changes described as found in man.

We have not seen the round-cell focus in skeletal muscle described by Gibson (1948), the infiltration in our specimens being always of a diffuse nature. The changes in the synovium were also more diffuse than those of the Allison-Ghormley type. There was no close correlation between the occurrence of swelling and histological findings. A number of swollen feet showed no detectable abnormalities, and on histological examination changes were found to have taken place in joints of some limbs which had appeared normal throughout the period of observation.

Preston (1942) stated that the joint lesions of rats which have been injected intracardially with PPLO are purulent in nature. The inflammation leads to an abscess involving all structures of the joint. Sabin and Warren (1940) state that a similarly induced arthritis in mice is primarily proliferative in nature, and in this respect shows some similarity to rheumatoid arthritis.

Our results lead us to agree that the primary inflammatory reaction is periarticular in nature, as shown to a greater or lesser extent by the joints of two-thirds of the rats examined. The type of lesion produced in rats by this particular strain of PPLO rather resembles that produced by Preston (1942). The frank abscesses, described by him as occurring in the joints, were not found, but the changes in the hearts resembled the purulent heart lesion he describes in the rat.

\section{Conclusions}

The histological picture in the rheumatic diseases differs in considerable detail from that found in our experimental animals, and we cannot conclude, therefore, that arthritis produced by PPLO in rats consistently resembles any one 
of the rheumatic diseases. This would not matter from the point of screening new compounds if it could be shown that any of the substances known to be useful in rheumatism therapy could prevent or influence the course of the condition, but as the arthritis we produced tended to spontaneous resolution, we do not feel that it can be used as a valid screening test.

\section{Summary}

Experiments in the production of arthritis in rats by the injection of pleuropneumonia-like organisms, histological and clinical findings, and the effect of passage and subculture on the pathogenicity of the organisms are described.

No close correlation was found between clinical appearance and histological changes, and the disease tended to spontaneous resolution. It is therefore concluded that the method cannot be used as a valid screening test for substances thought to be useful in the treatment of the rheumatic diseases.

We are greatly indebted to Dr. D. G. ff. Edward of the Wellcome Veterinary Station, who kindly provided the strain of PPLO used in this study, and to Dr. G. H. Bourne of the London Hospital Medical School, who did the histological examinations.

\section{REFERENCES}

Collier, W. A., and Staverman, G. J. (1940). Annals of the Rheumatic Diseases, 2, 58.

Dienes, L. (1945). J. Bact., 50, 441.

Edward, D. G. ff. (1947). J. gen. Microbiol., 1, 238. (1950). Ibid., 4, 4.

Findlay, G. M. (1946). Annals of the Rheumatic Diseases, 5, 153.

Gibson, H. J. (1948). "Textbook of the Rheumatic Diseases", ed. W. S. C. Copeman, p. 388. Livingstone, Edinburgh.

Klieneberger, E. (1938). J. Hyg., Camb., 38, 458.

- (1940). Ibid., 40, 204.

Kuzell, W. C., Gardner, G. M., Fairley, De Lorez M., and Tripi, H. B. (1949). Seventh International Congress on Rheumatic Diseases, New York, p. 52.

—, and Mankle, E. A. (1950). Proc. Soc. exp. Biol., N.Y., 74, 677.

Preston, W. S. (1942). J. infect. Dis., 70, 180.

Sabin, A. B. (1939). Science, 89, 228.

- (1941). Bact. Rev., 5, 1.

-

Tripi, H. B., and Kuzell, W. C. (1947). Stanford med. Bull., 5, 98.

—, Gardner, G. M., and Kuzell, W. C. (1949). Proc. Soc. exp. Biol., N.Y., $70,45$.

\section{Arthrite produite chez les Rats par des Organismes du Type Pleuro-pneumonique}

\section{RÉSUMÉ}

Les auteurs rapportent leurs expériences qui consistaient à provoquer l'arthrite chez les rats par des injections d'organismes du type pleuro-pneumonique. Ils décrivent les résultats histologiques et cliniques ainsi que les effets de passage et d'atténuation en culture sur le pouvoir pathogène des germes.

Ils n'ont pas trouvé de rapport entre l'aspect clinique et les altérations histologiques; la maladie tendait à la guérison spontanée. Ils en concluent que cette méthode n'a guère de valeur pour essayer des substances qu'on croit utiles dans le traitement de l'arthrite rhumatismale.

\section{Artritis producida en Ratas por Organismos del Tipo Pleuro-pneumónico}

RESUMEN

Los autores relatan sus experimentos en la producción de artritis en ratas mediante inyecciones de organismos del tipo pleuro-pneumónico. Describen los resultados histológicos y clínicos así como los efectos de pasaje y de atenuación en cultivo sobre el poder patógeno de los gérmenes.

No pudieron establecer correlación entre la apariencia clínica y los cambios histológicos; la enfermedad mostró tendencia de terminarse espontáneamente. Concluyen que este método no puede ser usado como prueba válida para substancias que se cree útiles para el tratamiento de las enfermedades reumáticas. 